\title{
Keragaan Empat Kultivar Kacang Hijau (Vigna radiata L.) Hasil Enkapsulasi Benih yang diperkaya dengan Mikoriza
}

\section{The Performance of 4 Green Bean (Vigna radiata L.) Cultivars Resulted from Mycchorizal Enrichment of Encapsulated Seed}

\author{
Dinda Tria Handayani, Taryono*) \\ Departemen Budidaya Pertanian, Fakultas Pertanian, Universitas Gadjah Mada \\ *) Penulis untuk koresponden Email: tariono60@ugm.ac.id
}

\begin{abstract}
Mycorrhiza is one of the efforts to overcome the lack of fertility in marginal land. This study aims to describe the role of mycorrhizae in the nursery, growth, and development of green beans and recommend proper encapsulation for mycorrhizal administration in green bean seeds. The research was conducted on May-October 2017 at Vegetalika House, Mallika Room and Mendel Room of Plant Breeding Laboratory, Department of Agricultural Cultivation, Faculty of Agriculture, Gadjah Mada University, Yogyakarta. The experimental design used was Completely Randomized Design (CRD) with 2 factors. Variables observed include seed quality, mycorrhizal infection, seed component properties, plant growth, and yield components. The overall data obtained were then analyzed using the Variance Analysis in Complete Random Design and comparing with Scott-Knott at 95\% confidence level. The results of the study provide information that the montmorillonite encapsulation on the Murai and Sriti cultivars is easily infected with mycorrhiza when aged 5 days after planting, which affects the ability to grow, develop, and produce seeds. The interaction between encapsulation and cultivar factors was found in the results of vigor index, hypothetical vigor index, fresh seed weight, plant height (60 days after planting), harvest height, number of harvest leaves, and flowering time.
\end{abstract}

Keywords : green bean cultivars, seed encapsulation, sand media

\section{INTISARI}

Mikoriza merupakan salah satu upaya untuk mengatasi kurangnya kesuburan di lahan marjinal. Penelitian ini bertujuan untuk mendeskripsikan peran mikoriza pada masa pembibitan, pertumbuhan, dan perkembangan kacang hijau serta merekomendasikan cara enkapsulasi yang tepat untuk pemberian mikoriza pada benih kacang hijau. Penelitian dilaksanakan pada bulan Mei-Oktober 2017 di Rumah Vegetalika, Ruang Mallika dan Ruang Mendel Laboratorium Pemuliaan Tanaman, Departemen Budidaya Pertanian, Fakultas Pertanian, Universitas Gadjah Mada, Yogyakarta. Rancangan percobaan yang digunakan adalah Rancangan Acak Lengkap (RAL) dengan 2 faktor. Variabel yang diamati meliputi mutu benih, infeksi mikoriza, sifat komponen bibit, pertumbuhan tanaman, dan komponen hasil. Keseluruhan data yang diperoleh dianalisis menggunakan Analisis Varian sesuai Rancangan Acak Lengkap dan dilakukan pembandingan dengan Scott-Knott pada taraf kepercayaan 95\%. Hasil penelitian memberikan informasi bahwa enkapsulasi montmorillonite pada kultivar Murai 
Dinda Tria Handayani et al., / Vegetalika. 2018. 7(4): 39-58

dan Sriti memberikan hasil yang terbaik. Interaksi antara faktor enkapsulasi dan kultivar ditemukan pada hasil indeks vigor, indeks vigor hipotetik, bobot segar bibit, tinggi tanaman 60 hst, tinggi tanaman panen, jumlah daun panen, dan waktu berbunga.

Kata kunci : kultivar kacang hijau, enkapsulasi benih, media pasir.

\section{PENDAHULUAN}

Kacang hijau (Vigna radiata L.) merupakan tanaman keluarga kacang ketiga setelah kedelai dan kacang tanah yang banyak dibudidayakan di Indonesia. Beberapa faktor penting yang mempengaruhi produktivitas kacang hijau yaitu pemilihan kultivar, ketersediaan lahan, kesuburan lahan, dan teknik budidaya. Luasan lahan tersedia saat ini lebih difokuskan untuk tanaman utama seperti padi, jagung, dan kedelai maka luasan lahan untuk pertanaman kacang hijau menjadi semakin sempit. Cara mengatasi masalah sempitnya luasan lahan yaitu dengan mengupayakan penanaman kacang hijau di daerah marjinal, utamanya pada lahan pasir. Indonesia memiliki 22 kultivar kacang hijau dan tidak seluruhnya dapat beradaptasi pada lahan pasir yang miskin hara. Oleh karena itu diperlukan pemilihan kultivar yang mampu menunjukkan tanggapan baik dan berdaya hasil tinggi pada lahan pasir.

Pengembangan kacang hijau pada lahan pasir dapat mengganggu pertumbuhan vegetatif karena tidak dapat tersedianya air dalam jumlah yang cukup dan rendahnya tingkat kesuburan (Wahyono dan Rahayu, 2014). Peningkatan efektivitas lahan dapat dilakukan dengan menambahkan agen hayati, salah satunya yaitu mikoriza. Menurut Nurhayati, dkk. (2014), mikoriza mampu meningkatkan ketersediaan hara P dan unsur mineral lainnya. Permanasari, dkk. (2016) menyatakan bahwa penggunaan mikoriza pada benih lebih baik daripada di media tanam namun mikoriza tidak dapat langsung menempel pada benih sehingga diperlukan bahan yang dapat merekatkan mikoriza pada benih. Melalui penelitian ini diharapkan mampu mendeskripsikan peran mikoriza pada masa pembibitan, pertumbuhan, dan perkembangan tanaman kacang hijau serta mampu memberikan rekomendasi cara enkapsulasi yang tepat untuk pemberian mikoriza pada benih kacang hijau.

\section{BAHAN DAN METODE PENELITIAN}

Penelitian ini dilaksanakan pada bulan Mei hingga Oktober 2017. Penelitian dilaksanakan di Rumah Vegetalika, serta Ruang Mallika dan Ruang Mendel Laboratorium Pemuliaan Tanaman, Departemen Budidaya Pertanian, Fakultas 
Dinda Tria Handayani et al., / Vegetalika. 2018. 7(4): 39-58

Pertanian, Universitas Gadjah Mada, Yogyakarta. Obyek penelitian berupa kacang hijau (Vigna radiata L.) kultivar Kenari, Kutilang, Murai, dan Sriti. Percobaan disusun dalam rancangan lingkungan Acak Lengkap (RAL) yang terdiri dari 2 faktor yaitu enkapsulasi dan kultivar. Faktor enkapsulasi benih terdiri dari kontrol (E1), tanpa enkapsulasi (E2), enkapsulasi kaolinite (E3), dan enkapsulasi montmorillonite (E4) sedangkan faktor kultivar terdiri dari Kenari (K1), Kutilang (K2), Murai (K3), dan Sriti (K4). Terdapat 16 kombinasi perlakuan dengan jumlah ulangan 4 kali sehingga ada 64 unit.

Variabel pengamatan terdiri dari mutu benih, infeksi mikoriza, sifat komponen bibit, pertumbuhan tanaman, dan komponen hasil. Pengamatan mutu benih terdiri dari gaya berkecambah dan indeks vigor. Pengamatan sifat komponen bibit terdiri dari bobot segar, volume akar, dan kehijauan daun sedangkan pengamatan infeksi mikoriza diamati sebanyak 3 kali setiap 5 hari sekali. Pengamatan pertumbuhan dilakukan terhadap tinggi tanaman dan jumlah daun setiap 20 hari sebanyak 3 kali. Pengamatan komponen hasil dilakukan pada saat tanaman siap panen pada umur 60 hst. Pengamatan meliputi tinggi tanaman, jumlah daun, panjang akar, volume akar, waktu pembungaan, umur panen, bobot segar tanaman, bobot kering tanaman, jumlah polong, jumlah biji per polong, bobot biji per tanaman, dan bobot 100 biji. Keseluruhan data yang diperoleh selanjutnya dianalisis menggunakan Analisis Varian (ANOVA) sesuai Rancangan Acak Lengkap dengan perangkat lunak Rx64 3.3.1. Apabila terjadi interaksi antara kultivar dan enkapsulasi, pembandingan dilakukan terhadap kombinasi perlakuannya, sedangkan apabila interaksinya tidak nyata, tetapi faktornya nyata, maka pembandingan dilakukan terhadap aras dari faktor tersebut. Pembandingan dilakukan dengan Scott-Knott pada taraf kepercayaan 95\% sehingga dapat diketahui kultivar dan cara enkapsulasi yang paling tepat.

\section{HASIL DAN PEMBAHASAN}

Perkecambahan merupakan proses awal pertumbuhan individu baru pada tanaman. Menurut Coppeland (1980), pada saat perkecambahan terjadi proses imbibisi, aktivasi enzim, inisiasi pertumbuhan embrio, peretakan kulit biji, serta munculnya radikula dan plumula. 
Dinda Tria Handayani et al., / Vegetalika. 2018. 7(4): 39-58

\begin{tabular}{lccccc}
\hline \multirow{2}{*}{ Kultivar } & \multicolumn{5}{c}{ Enkapsulasi } \\
\cline { 2 - 5 } & Kontrol & $\begin{array}{c}\text { Tanpa } \\
\text { Enkapsulasi }\end{array}$ & $\begin{array}{c}\text { Enkapsulasi } \\
\text { Kaolinite }\end{array}$ & $\begin{array}{c}\text { Enkapsulasi } \\
\text { Montmorillonite }\end{array}$ & Rerata \\
\hline Kenari & 91 & 94 & 98 & 100 & $95,75 \mathrm{a}$ \\
Kutilang & 92 & 92 & 98 & 100 & $95,50 \mathrm{a}$ \\
Murai & 90 & 91 & 98 & 99 & $94,50 \mathrm{a}$ \\
Sriti & 93 & 95 & 99 & 98 & $96,25 \mathrm{a}$ \\
\hline \multicolumn{1}{c}{ Rerata } & $91,50 \mathrm{~b}$ & $93 \mathrm{~b}$ & $98,25 \mathrm{a}$ & $99,25 \mathrm{a}$ & - \\
\hline \multicolumn{1}{c}{ CV } & 2,99 & & & &
\end{tabular}

(-) Tidak ada interaksi antara kedua faktor.

Angka-angka pada kolom atau baris yang sama diikuti oleh huruf yang sama, tidak berbeda nyata pada uji Scott Knott dengan taraf kepercayaan 95\%.

Berdasarkan hasil pengamatan, gaya berkecambah benih kacang hijau yang diuji memiliki gaya berkecambah diatas $90 \%$. Pada perlakuan enkapsulasi, air lebih mudah tersedia bagi benih karena mineral lempung memiliki kemampuan menyimpan air lebih banyak. Semakin halus partikel lempung maka semakin besar kemampuan menyimpan air. Menurut Novita dan Suwarno (2014), penanaman benih pada lingkungan sub-optimum tidak mempengaruhi gaya berkecambah benih meskipun menggunakan kultivar yang unggul sekalipun.

Tabel 2. Indeks Vigor Faktor Enkapsulasi

\begin{tabular}{lccccc}
\hline \multirow{2}{*}{ Kultivar } & \multicolumn{5}{c}{ Enkapsulasi } \\
\cline { 2 - 5 } & Kontrol & $\begin{array}{c}\text { Tanpa } \\
\text { Enkapsulasi }\end{array}$ & $\begin{array}{c}\text { Enkapsulasi } \\
\text { Kaolinite }\end{array}$ & $\begin{array}{c}\text { Enkapsulasi } \\
\text { Montmorillonite }\end{array}$ & Rerata \\
\hline Kenari & $11,16 \mathrm{a}$ & $16,20 \mathrm{a}$ & $12,91 \mathrm{~b}$ & $13,95 \mathrm{a}$ & 13,56 \\
Kutilang & $12,70 \mathrm{a}$ & $11,83 \mathrm{~b}$ & $13,29 \mathrm{~b}$ & $12,79 \mathrm{a}$ & 12,65 \\
Murai & $13,75 \mathrm{a}$ & $13,41 \mathrm{~b}$ & $13,58 \mathrm{~b}$ & $14,54 \mathrm{a}$ & 13,82 \\
Sriti & $12,58 \mathrm{a}$ & $12,33 \mathrm{~b}$ & $15,08 \mathrm{a}$ & $12,62 \mathrm{a}$ & 13,15 \\
\hline \multicolumn{1}{c}{ Rerata } & 12,55 & 13,44 & 13,72 & 13,48 & + \\
\hline \multicolumn{7}{c}{ CV } & 10,43 & & & & \\
\hline
\end{tabular}

Keterangan :

(+) Terdapat interaksi antara kedua faktor.

Angka-angka pada kolom atau baris yang sama diikuti oleh huruf yang sama, tidak berbeda nyata pada uji Scott Knott dengan taraf kepercayaan 95\%. 
Dinda Tria Handayani et al., / Vegetalika. 2018. 7(4): 39-58

Tabel 3. Indeks Vigor Faktor Kultivar

\begin{tabular}{lccccc}
\hline \multirow{2}{*}{ Kultivar } & \multicolumn{5}{c}{ Enkapsulasi } \\
\cline { 2 - 5 } & Kontrol & $\begin{array}{c}\text { Tanpa } \\
\text { Enkapsulasi }\end{array}$ & $\begin{array}{c}\text { Enkapsulasi } \\
\text { Kaolinite }\end{array}$ & $\begin{array}{c}\text { Enkapsulasi } \\
\text { Montmorillonite }\end{array}$ & Rerata \\
\hline Kenari & $11,16 \mathrm{c}$ & $16,20 \mathrm{a}$ & $12,91 \mathrm{~b}$ & $13,95 \mathrm{~b}$ & 13,56 \\
Kutilang & $12,70 \mathrm{a}$ & $11,83 \mathrm{a}$ & $13,29 \mathrm{a}$ & $12,79 \mathrm{a}$ & 12,65 \\
Murai & $13,75 \mathrm{a}$ & $13,41 \mathrm{a}$ & $13,58 \mathrm{a}$ & $14,54 \mathrm{a}$ & 13,82 \\
Sriti & $12,58 \mathrm{~b}$ & $12,33 \mathrm{~b}$ & $15,08 \mathrm{a}$ & $12,62 \mathrm{~b}$ & 13,15 \\
\hline \multicolumn{1}{c}{ Rerata } & 12,55 & 13,44 & 13,72 & 13,48 & + \\
\hline \multicolumn{1}{c}{ CV } & 10,43 & & & & \\
\hline
\end{tabular}

Keterangan :

(+) Terdapat interaksi antara kedua faktor.

Angka-angka pada kolom atau baris yang sama diikuti oleh huruf yang sama, tidak berbeda nyata pada uji Scott Knott dengan taraf kepercayaan 95\%.

Kacang hijau yang diberi mikoriza mampu menghasilkan indeks vigor yang lebih tinggi jika dibandingkan dengan tanaman kontrol. Kaolinite memiliki pori lebih besar jika dibandingkan dengan montmorillonite. Pori-pori tersebut menjadi tempat berkembangnya mikoriza. Semakin besar ukuran pori tanah maka kemungkinan kemampuan perkembangan mikoriza lebih tinggi. Ketika benih berkecambah, mikoriza berasosiasi dengan akar bibit untuk mencari bahan-bahan penting dalam media tanam yang dibutuhkan oleh tanaman untuk tumbuh dan berkembang seperti air, unsur hara, dan bahan-bahan penting lainnya. 
Dinda Tria Handayani et al., / Vegetalika. 2018. 7(4): 39-58
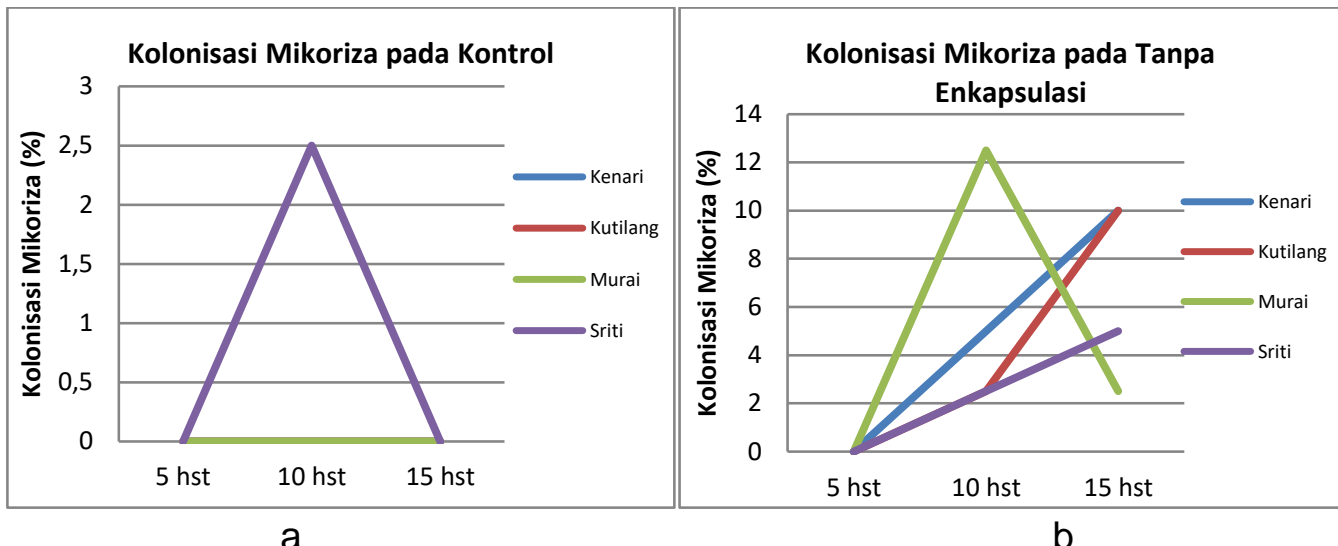

a
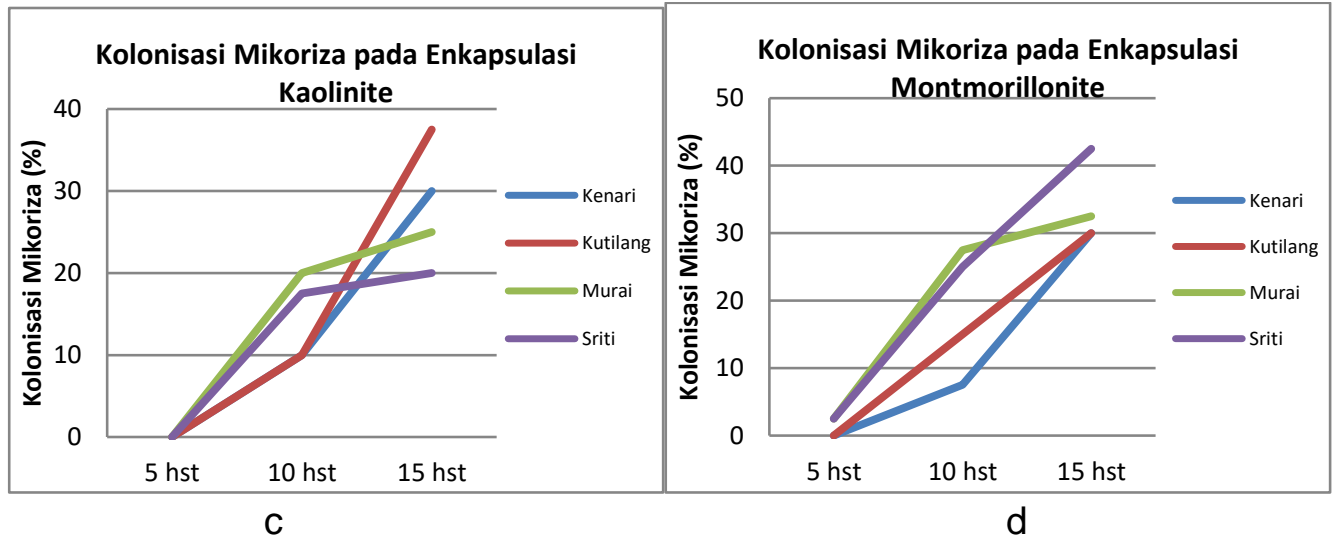

Gambar 1. Laju Kolonisasi Mikoriza beberapa Kultivar Kacang Hijau pada Perlakuan Enkapsulasi: a. Kontrol, b. Tanpa Enkapsulasi, c. Enkapsulasi Kaolinite, dan d. Enkapsulasi Montmorillonite

Hasil percobaan (Gambar 1) menunjukkan bahwa terjadi peningkatan kolonisasi akar oleh mikoriza dari pengamatan pertama hingga ketiga. Pada pengamatan pertama sudah ditemukan adanya infeksi pada enkapsulasi montmorillonite kultivar Murai dan Sriti. Pada perlakuan pemberian mikoriza, benih yang dienkapsulasi menunjukkan adanya infeksi mikoriza yang lebih besar daripada tanpa enkapsulasi karena molase pada benih enkapsulasi lebih mudah tersedia untuk mikoriza. Molase pada benih yang tidak dienkapsulasi dapat menempel pada wadah benih, media tanam, serta alat penanam sehingga tidak keseluruhan molase dapat dimanfaatkan oleh mikoriza. 
Dinda Tria Handayani et al., / Vegetalika. 2018. 7(4): 39-58

Tabel 4. Bobot Segar Bibit (gram) Faktor Enkapsulasi

\begin{tabular}{lccccc}
\hline \multirow{2}{*}{ Kultivar } & \multicolumn{5}{c}{ Enkapsulasi } \\
\cline { 2 - 5 } & Kontrol & $\begin{array}{c}\text { Tanpa } \\
\text { Enkapsulasi }\end{array}$ & $\begin{array}{c}\text { Enkapsulasi } \\
\text { Kaolinite }\end{array}$ & $\begin{array}{c}\text { Enkapsulasi } \\
\text { Montmorillonite }\end{array}$ & Rerata \\
\hline Kenari & $0,94 \mathrm{a}$ & $1,42 \mathrm{a}$ & $1,08 \mathrm{~b}$ & $1,86 \mathrm{~b}$ & 1,33 \\
Kutilang & $1,10 \mathrm{a}$ & $1,10 \mathrm{a}$ & $2,44 \mathrm{a}$ & $2,26 \mathrm{a}$ & 1,73 \\
Murai & $1,06 \mathrm{a}$ & $1,21 \mathrm{a}$ & $0,99 \mathrm{~b}$ & $1,57 \mathrm{c}$ & 1,21 \\
Sriti & $0,81 \mathrm{a}$ & $0,77 \mathrm{~b}$ & $0,85 \mathrm{~b}$ & $1,58 \mathrm{c}$ & 1,00 \\
\hline \multicolumn{1}{c}{ Rerata } & 0,98 & 1,13 & 1,34 & 1,82 & + \\
\hline \multicolumn{1}{c}{ CV } & 15,49 & & & & \\
\hline
\end{tabular}

Keterangan :

(+) Terdapat interaksi antara kedua faktor.

Angka-angka pada kolom atau baris yang sama diikuti oleh huruf yang sama, tidak berbeda nyata pada uji Scott Knott dengan taraf kepercayaan 95\%.

Tabel 5. Bobot Segar Bibit (gram) Faktor Kultivar

\begin{tabular}{cccccc}
\hline \multirow{2}{*}{ Kultivar } & \multicolumn{4}{c}{ Cara Pemberian Mikoriza } & Rerata \\
\cline { 2 - 5 } & Kontrol & $\begin{array}{c}\text { Tanpa } \\
\text { Enkapsulasi }\end{array}$ & $\begin{array}{c}\text { Enkapsulasi } \\
\text { Kaolinite }\end{array}$ & $\begin{array}{c}\text { Enkapsulasi } \\
\text { Montmorillonite }\end{array}$ & \\
\hline Kenari & $0,94 \mathrm{c}$ & $1,42 \mathrm{~b}$ & $1,08 \mathrm{c}$ & $1,86 \mathrm{a}$ & 1,33 \\
Kutilang & $1,10 \mathrm{~b}$ & $1,10 \mathrm{~b}$ & $2,44 \mathrm{a}$ & $2,26 \mathrm{a}$ & 1,73 \\
Murai & $1,06 \mathrm{~b}$ & $1,21 \mathrm{~b}$ & $0,99 \mathrm{~b}$ & $1,57 \mathrm{a}$ & 1,21 \\
Sriti & $0,81 \mathrm{~b}$ & $0,77 \mathrm{~b}$ & $0,85 \mathrm{~b}$ & $1,58 \mathrm{a}$ & 1,00 \\
\hline Rerata & 0,98 & 1,13 & 1,34 & 1,82 & + \\
\hline CV & 15,49 & & & & \\
\hline
\end{tabular}

Keterangan :

(+) Terdapat interaksi antara kedua faktor.

Angka-angka pada kolom atau baris yang sama diikuti oleh huruf yang sama, tidak berbeda nyata pada uji Scott Knott dengan taraf kepercayaan 95\%.

Kultivar kutilang memiliki bobot segar tertinggi karena bibit kultivar ini memiliki morfologi yang tinggi dengan daun yang lebar. Mikoriza mampu meningkatkan bobot akar karena adanya peningkatan pembentukan akar lateral. Banyaknya jumlah akar lateral disebabkan oleh peningkatan sintesis IBA (asam indol butirat). Selain itu, mikoriza juga mampu meningkatkan panjang akar. Semakin panjang akar maka jangkuan serapan hara oleh akar menjadi semakin tinggi. Kenaikan bobot dan panjang akar maka akan meningkatkan nilai volume akar (Widiastuti, dkk., 2003). 
Dinda Tria Handayani et al., / Vegetalika. 2018. 7(4): 39-58

Tabel 6. Volume Akar Bibit (ml)

\begin{tabular}{lccccc}
\hline \multirow{2}{*}{ Kultivar } & \multicolumn{4}{c}{ Enkapsulasi } & Rerata \\
\cline { 2 - 5 } & Kontrol & $\begin{array}{c}\text { Tanpa } \\
\text { Enkapsulasi }\end{array}$ & $\begin{array}{c}\text { Enkapsulasi } \\
\text { Kaolinite }\end{array}$ & $\begin{array}{c}\text { Enkapsulasi } \\
\text { Montmorillonite }\end{array}$ & \\
\hline Kenari & 0,15 & 0,23 & 0,35 & 0,40 & $0,28 \mathrm{~b}$ \\
Kutilang & 0,13 & 0,18 & 0,33 & 0,35 & $0,25 \mathrm{~b}$ \\
Murai & 0,33 & 0,35 & 0,50 & 0,53 & $0,43 \mathrm{a}$ \\
Sriti & 0,23 & 0,30 & 0,58 & 0,65 & $0,44 \mathrm{a}$ \\
\hline \multicolumn{1}{c}{ Rerata } & $0,21 \mathrm{~b}$ & $0,27 \mathrm{~b}$ & $0,44 \mathrm{a}$ & $0,48 \mathrm{a}$ & - \\
\hline \multicolumn{1}{c}{ CV } & 31,96 & & & & \\
\hline
\end{tabular}

Keterangan :

(-) Tidak terdapat interaksi antara kedua faktor.

Angka-angka pada kolom atau baris yang sama diikuti oleh huruf yang sama, tidak berbeda nyata pada uji Scott Knott dengan taraf kepercayaan 95\%.

Kultivar Sriti menghasilkan nilai volume akar yang tertinggi. Sriti merupakan salah satu kultivar yang memiliki daya adaptasi yang baik terhadap daerah tercekam air karena pertumbuhan akar yang baik. Dalam kondisi cekaman air, akar akan tumbuh lebih panjang ke dalam lapisan-lapisan tanah. Tanaman yang kekurangan air memiliki kemampuan mengambil air secara maksimal dengan perluasan dan kedalaman yang semakin meningkat.

Tabel 7. Kehijauan Daun Bibit

\begin{tabular}{lccccc}
\hline \multirow{2}{*}{ Kultivar } & \multicolumn{5}{c}{ Enkapsulasi } \\
\cline { 2 - 5 } & Kontrol & $\begin{array}{c}\text { Tanpa } \\
\text { Enkapsulasi }\end{array}$ & $\begin{array}{c}\text { Enkapsulasi } \\
\text { Kaolinite }\end{array}$ & $\begin{array}{c}\text { Enkapsulasi } \\
\text { Montmorillonite }\end{array}$ & Rerata \\
\hline Kenari & 3,00 & 3,00 & 3,00 & 3,50 & $3,13 \mathrm{~b}$ \\
Kutilang & 3,00 & 3,00 & 3,50 & 3,75 & $3,31 \mathrm{a}$ \\
Murai & 2,75 & 3,00 & 3,00 & 3,00 & $2,94 \mathrm{~b}$ \\
Sriti & 3,00 & 3,00 & 3,00 & 3,00 & $3,00 \mathrm{~b}$ \\
\hline \multicolumn{1}{c}{ Rerata } & $2,94 \mathrm{~b}$ & $3,00 \mathrm{~b}$ & $3,13 \mathrm{~b}$ & $3,31 \mathrm{a}$ & - \\
\hline \multicolumn{1}{c}{ CV } & 8,72 & & & & \\
\hline
\end{tabular}

Keterangan :

(-) Tidak terdapat interaksi antara kedua faktor.

Angka-angka pada kolom atau baris yang sama diikuti oleh huruf yang sama, tidak berbeda nyata pada uji Scott Knott dengan taraf kepercayaan 95\%.

Mikoriza mampu meningkatkan kemampuan menyerap unsur $\mathrm{Cu}$ yang berperan dalam pembentukan klorofil daun dan aktivasi enzimatis (Rahayu, 2010). Tanaman yang diinokulasi mikoriza menunjukkan peningkatan yang signifikan dalam klorofil a, b, dan kandungan klorofil total karena adanya peningkatan konduktansi stomata, laju 
Dinda Tria Handayani et al., / Vegetalika. 2018. 7(4): 39-58

fotosintesis, aktivitas transpirasi, dan peningkatan pertumbuhan tanaman (Havugimana, et al., 2015).

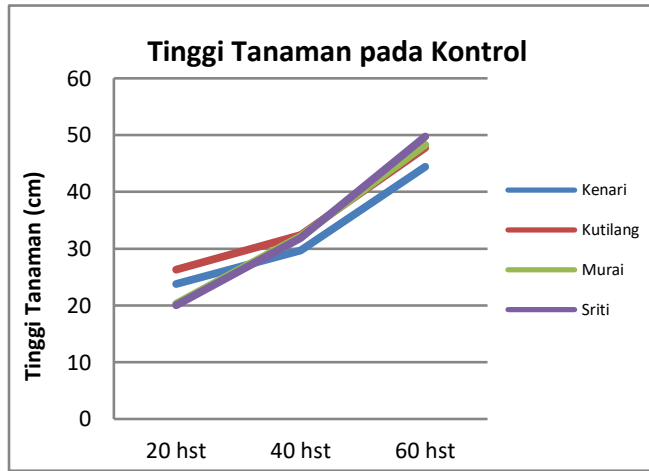

a

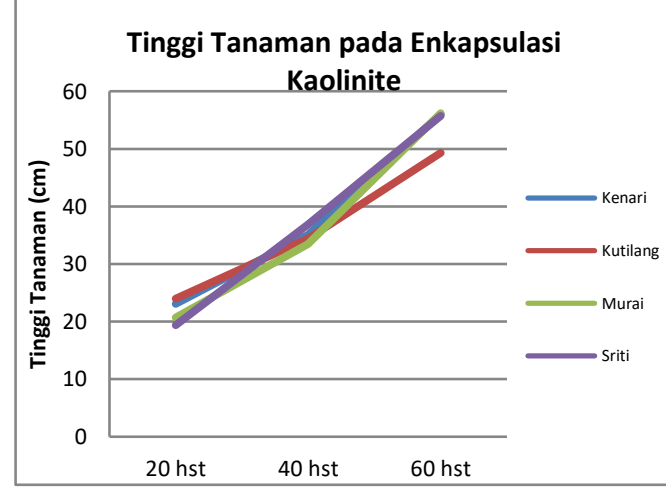

C

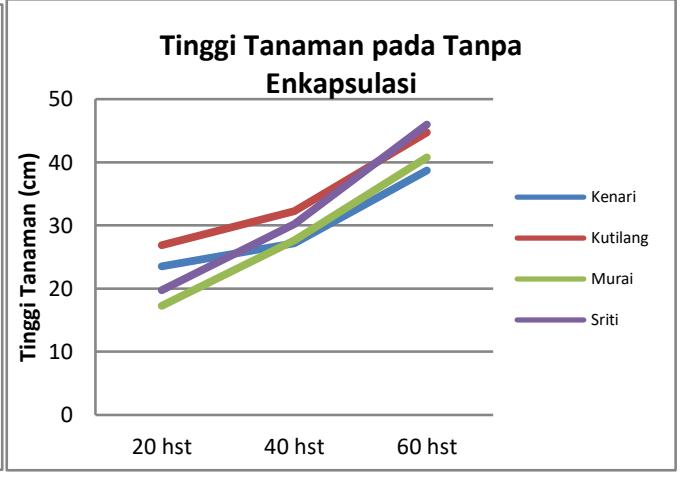

b

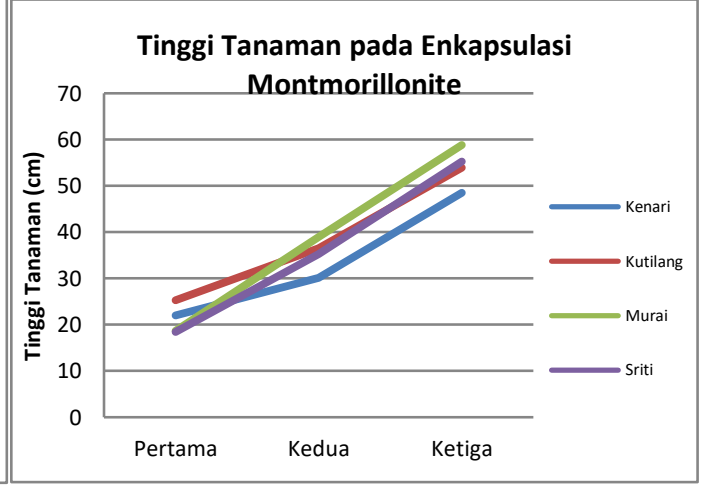

d

Gambar 2. Pertumbuhan Tinggi Tanaman beberapa Kultivar Kacang Hijau pada perlakuan

Enkapsulasi : a. Kontrol, b. Tanpa Enkapsulasi, c. Enkapsulasi Kaolinite, d. Enkapsulasi Montmorillonite.

Berdasarkan hasil pertumbuhan tinggi tanaman (Gambar 2) dapat diketahui bahwa pertambahan umur kacang hijau diikuti dengan pertambahan tinggi tanaman. Penambahan bahan pelapis dan perekat mampu meningkatkan jumlah spora yang menempel pada benih sehingga kecepatan mikoriza dalam menginfeksi akar menjadi lebih baik. Peningkatan infeksi mikoriza pada akar tanaman berkorelasi positif terhadap pertumbuhan tanaman terutama tinggi tanaman (Rahayu, 2010). Mikoriza mampu meningkatkan ketahanan kekeringan pada keluarga tanaman kacang-kacangan karena mikoriza menyebabkan resistensi akar terhadap gerakan air menurun sehingga transportasi air ke akar meningkat (Sampurno, dkk., 2010). 
Dinda Tria Handayani et al., / Vegetalika. 2018. 7(4): 39-58
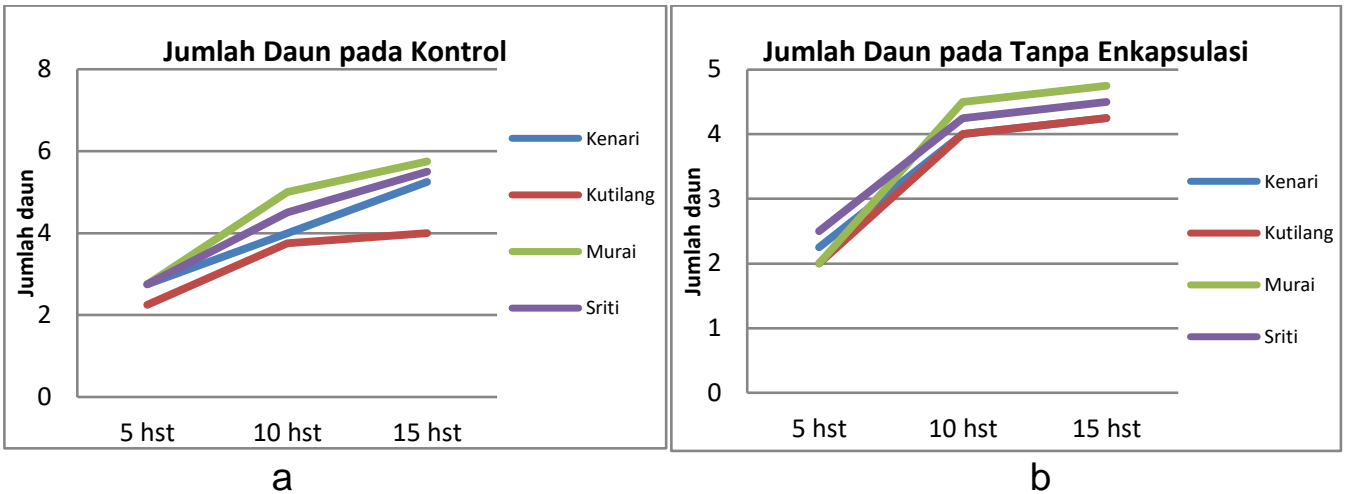

a

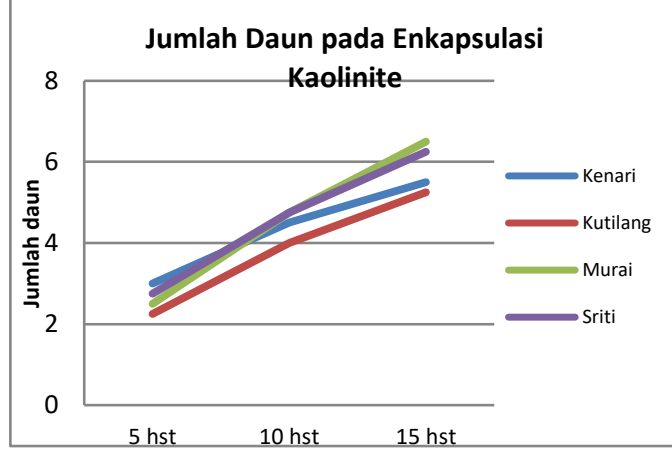

C

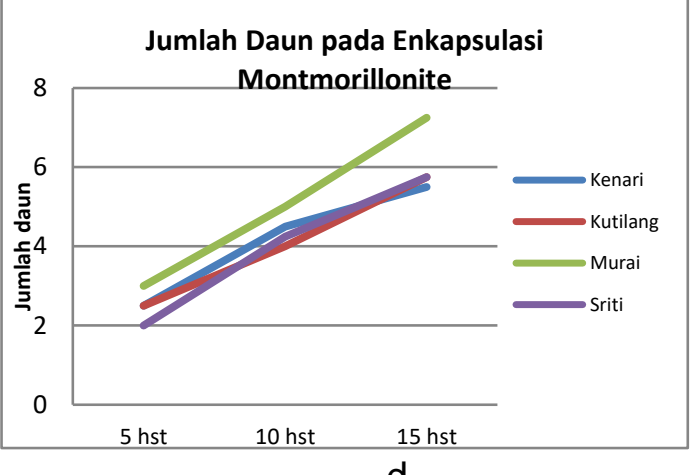

d

Gambar 3. Grafik Pertumbuhan Jumlah Daun beberapa Kultivar Kacang Hijau pada Perlakuan Enkapsulasi : a. Kontrol, b. Tanpa Enkapsulasi, c. Enkapsulasi Kaolinite, d. Enkapsulasi Montmorillonite

Berdasarkan hasil pertumbuhan jumlah daun (Gambar 3) dapat diketahui bahwa pertambahan umur kacang hijau diikuti dengan pertambahan jumlah daun. Peningkatan jumlah daun pada seluruh kultivar setiap dilakukan pengamatan juga disebabkan oleh ketahanan tanaman terhadap OPT. Mikoriza memiliki peranan dalam mengendalikan patogen yang dapat mempengaruhi tanaman inang. Mikoriza memanfaatkan karbohidrat sebelum dikeluarkan sehingga patogen tidak mendapatkan makanan. Mikoriza mampu membentuk substansi antibiotik untuk menghambat patogen dan memicu perkembangan mikroba saprotifik di sekitar perakaran (Wicaksono, dkk., 2014). 
Dinda Tria Handayani et al., / Vegetalika. 2018. 7(4): 39-58

Tabel 8. Tinggi Tanaman Panen pada 60 hst (cm) Faktor Enkapsulasi

\begin{tabular}{lccccc}
\hline \multirow{2}{*}{ Kultivar } & \multicolumn{5}{c}{ Enkapsulasi } \\
\cline { 2 - 5 } & Kontrol & $\begin{array}{c}\text { Tanpa } \\
\text { Enkapsulasi }\end{array}$ & $\begin{array}{c}\text { Enkapsulasi } \\
\text { Kaolinite }\end{array}$ & $\begin{array}{c}\text { Enkapsulasi } \\
\text { Montmorillonite }\end{array}$ & Rerata \\
\hline Kenari & $44,47 \mathrm{a}$ & $41,65 \mathrm{a}$ & $56,70 \mathrm{a}$ & $48,65 \mathrm{~b}$ & 47,87 \\
Kutilang & $48,05 \mathrm{a}$ & $45,70 \mathrm{a}$ & $50,57 \mathrm{~b}$ & $54,02 \mathrm{a}$ & 49,59 \\
Murai & $50,67 \mathrm{a}$ & $45,07 \mathrm{a}$ & $57,17 \mathrm{a}$ & $58,77 \mathrm{a}$ & 52,93 \\
Sriti & $50,72 \mathrm{a}$ & $46,85 \mathrm{a}$ & $55,65 \mathrm{a}$ & $56,87 \mathrm{a}$ & 52,53 \\
\hline \multicolumn{1}{c}{ Rerata } & 48,48 & 44,82 & 55,03 & 54,58 & + \\
\hline \multicolumn{7}{c}{ CV } & 6,33 & & & \\
\hline
\end{tabular}

Keterangan :

(+) Terdapat interaksi antara kedua faktor.

Angka-angka pada kolom atau baris yang sama diikuti oleh huruf yang sama, tidak berbeda nyata pada uji Scott Knott dengan taraf kepercayaan 95\%.

Tabel 9. Tinggi Tanaman Panen pada 60 hst (cm) Faktor Kultivar

\begin{tabular}{lccccc}
\hline \multirow{2}{*}{ Kultivar } & \multicolumn{5}{c}{ Enkapsulasi } \\
\cline { 2 - 5 } & Kontrol & $\begin{array}{c}\text { Tanpa } \\
\text { Enkapsulasi }\end{array}$ & $\begin{array}{c}\text { Enkapsulasi } \\
\text { Kaolinite }\end{array}$ & $\begin{array}{c}\text { Enkapsulasi } \\
\text { Montmorillonite }\end{array}$ & Rerata \\
\hline Kenari & $44,47 \mathrm{c}$ & $41,65 \mathrm{c}$ & $56,70 \mathrm{a}$ & $48,65 \mathrm{~b}$ & 47,87 \\
Kutilang & $48,05 \mathrm{a}$ & $45,70 \mathrm{a}$ & $50,57 \mathrm{a}$ & $54,02 \mathrm{a}$ & 49,59 \\
Murai & $50,67 \mathrm{~b}$ & $45,07 \mathrm{c}$ & $57,17 \mathrm{a}$ & $58,77 \mathrm{a}$ & 52,93 \\
Sriti & $50,72 \mathrm{~b}$ & $46,85 \mathrm{c}$ & $55,65 \mathrm{a}$ & $56,87 \mathrm{a}$ & 52,53 \\
\hline \multicolumn{1}{c}{ Rerata } & 48,48 & 44,82 & 55,03 & 54,58 & + \\
\hline \multicolumn{1}{c}{ CV } & 6,33 & & & \\
\hline
\end{tabular}

Keterangan :

(+) Terdapat interaksi antara kedua faktor.

Angka-angka pada kolom atau baris yang sama diikuti oleh huruf yang sama, tidak berbeda nyata pada uji Scott Knott dengan taraf kepercayaan 95\%.

Pertumbuhan tinggi tanaman terus meningkat dari tanaman muda hingga tanaman memasuki masa dewasa, kemudian terjadi penurunan ketika tanaman tua. Pertumbuhan tanaman tua lebih terfokus pada pertumbuhan generatif untuk mempertahankan kelestarian tanaman. Berdasarkan hasil pengukuran, pada setiap pengamatan terjadi peningkatan tinggi tanaman sekitar $10 \mathrm{~cm}$ hingga $20 \mathrm{~cm}$ namun pada pengukuran tinggi tanaman saat panen hanya terjadi peningkatan $1 \mathrm{~cm}$ sampai $2 \mathrm{~cm}$ saja. 
Dinda Tria Handayani et al., / Vegetalika. 2018. 7(4): 39-58

Tabel 10. Pertumbuhan Jumlah Daun pada 60 hst

\begin{tabular}{lccccc}
\hline \multirow{2}{*}{ Kultivar } & \multicolumn{5}{c}{ Enkapsulasi } \\
\cline { 2 - 5 } & Kontrol & $\begin{array}{c}\text { Tanpa } \\
\text { Enkapsulasi }\end{array}$ & $\begin{array}{c}\text { Enkapsulasi } \\
\text { Kaolinite }\end{array}$ & $\begin{array}{c}\text { Enkapsulasi } \\
\text { Montmorillonite }\end{array}$ & Rerata \\
\hline Kenari & 5,25 & 4,25 & 5,50 & 5,50 & $5,13 \mathrm{~b}$ \\
Kutilang & 4,00 & 4,25 & 5,25 & 5,75 & $4,81 \mathrm{~b}$ \\
Murai & 5,75 & 4,75 & 6,50 & 7,25 & $6,06 \mathrm{a}$ \\
Sriti & 5,50 & 4,50 & 6,25 & 5,75 & $5,50 \mathrm{a}$ \\
\hline \multicolumn{1}{c}{ Rerata } & $5,13 \mathrm{~b}$ & $4,44 \mathrm{c}$ & $5,88 \mathrm{a}$ & $6,06 \mathrm{a}$ & - \\
\hline \multicolumn{1}{c}{ CV } & 15,3 & & & & \\
\hline
\end{tabular}

Keterangan :

(-) Tidak terdapat interaksi antara kedua faktor.

Angka-angka pada kolom atau baris yang sama diikuti oleh huruf yang sama, tidak berbeda nyata pada uji Scott Knott dengan taraf kepercayaan 95\%.

Mikoriza mampu membantu peningkatan aktivitas enzimatis dan fisiologis dalam tubuh tanaman sehingga meningkatkan pertumbuhan tanaman. Mikoriza mampu meningkatkan serapan air. Peningkatan jumlah air terserap ini mampu memicu pertumbuhan tanaman melalui pembelahan, pembesaran, dan pemanjangan sel yang salah satunya ditandai dengan meningkatnya jumlah daun tanaman.

Tabel 11. Panjang Akar Saat Panen (cm)

\begin{tabular}{|c|c|c|c|c|c|}
\hline \multirow[b]{2}{*}{ Kultivar } & \multicolumn{4}{|c|}{ Enkapsulasi } & \multirow[b]{2}{*}{ Rerata } \\
\hline & Kontrol & $\begin{array}{c}\text { Tanpa } \\
\text { Enkapsulasi }\end{array}$ & $\begin{array}{c}\text { Enkapsulasi } \\
\text { Kaolinite }\end{array}$ & $\begin{array}{c}\text { Enkapsulasi } \\
\text { Montmorillonite }\end{array}$ & \\
\hline Kenari & 24,92 & 24,12 & 29,72 & 33,00 & $27,94 \mathrm{a}$ \\
\hline Kutilang & 23,70 & 23,07 & 33,37 & 35,32 & $28,87 \mathrm{a}$ \\
\hline Murai & 26,87 & 22,57 & 36,05 & 32,50 & $29,50 \mathrm{a}$ \\
\hline Sriti & 25,72 & 24,22 & 33,72 & 38,45 & $30,53 \mathrm{a}$ \\
\hline Rerata & $25,31 b$ & $23,50 \mathrm{~b}$ & $33,22 \mathrm{a}$ & $34,82 \mathrm{a}$ & - \\
\hline $\mathrm{CV}$ & 20,74 & & & & \\
\hline
\end{tabular}

Keterangan :

(-) Tidak terdapat interaksi antara kedua faktor.

Angka-angka pada kolom atau baris yang sama diikuti oleh huruf yang sama, tidak berbeda nyata pada uji Scott Knott dengan taraf kepercayaan 95\%.

Kultivar Sriti memiliki akar yang terpanjang karena Sriti merupakan salah satu kultivar yang mampu beradaptasi dengan daerah tercekam air. Kekurangan unsur hara maupun pada keadaan tercekap air mampu memicu pertumbuhan akar lebih cepat. Hal ini dikarenakan akar akan berusaha lebih keras dalam memenuhi kebutuhannya pada media tumbuhnya sehingga pertumbuhan akar cenderung lebih panjang dan jangkauannya lebih luas (Ai dan Torey, 2013). 
Dinda Tria Handayani et al., / Vegetalika. 2018. 7(4): 39-58

Tabel 12. Volume Akar Saat panen (ml)

\begin{tabular}{cccccc}
\hline \multirow{2}{*}{ Kultivar } & \multicolumn{5}{c}{ Enkapsulasi } \\
\cline { 2 - 5 } & Kontrol & $\begin{array}{c}\text { Tanpa } \\
\text { Enkapsulasi }\end{array}$ & $\begin{array}{c}\text { Enkapsulasi } \\
\text { Kaolinite }\end{array}$ & $\begin{array}{c}\text { Enkapsulasi } \\
\text { Montmorillonite }\end{array}$ & Rerata \\
\hline Kenari & 3,20 & 4,03 & 5,73 & 6,45 & $4,85 \mathrm{~b}$ \\
Kutilang & 4,23 & 4,83 & 5,58 & 5,48 & $5,03 \mathrm{~b}$ \\
Murai & 5,85 & 6,13 & 8,05 & 10,28 & $7,58 \mathrm{a}$ \\
Sriti & 5,68 & 6,38 & 8,03 & 9,63 & $7,43 \mathrm{a}$ \\
\hline Rerata & $4,74 \mathrm{~b}$ & $5,34 \mathrm{~b}$ & $6,84 \mathrm{a}$ & $7,96 \mathrm{a}$ & - \\
\hline CV & 19,76 & & & & \\
\hline
\end{tabular}

Keterangan :

(-) Tidak terdapat interaksi antara kedua faktor.

Angka-angka pada kolom atau baris yang sama diikuti oleh huruf yang sama, tidak berbeda nyata pada uji Scott Knott dengan taraf kepercayaan 95\%.

Enkapsulasi mikoriza mampu meningkatkan jumlah akar serabut, memperbesar diameter akar, dan meningkatkan jumlah nodul akar. Pemberian mikoriza pada benih mampu memberikan hasil volume akar yang lebih baik jika dibandingkan dengan kontrol. Simbiosis mikoriza dengan akar tanaman dapat meningkatkan volume akar kacang hijau.

Tabel 13. Waktu Pembungaan (hari) Faktor Enkapsulasi

\begin{tabular}{|c|c|c|c|c|c|}
\hline \multirow[b]{2}{*}{ Kultivar } & \multicolumn{4}{|c|}{ Enkapsulasi } & \multirow[b]{2}{*}{ Rerata } \\
\hline & Kontrol & $\begin{array}{c}\text { Tanpa } \\
\text { Enkapsulasi }\end{array}$ & $\begin{array}{c}\text { Enkapsulasi } \\
\text { Kaolinite }\end{array}$ & $\begin{array}{c}\text { Enkapsulasi } \\
\text { Montmorillonite }\end{array}$ & \\
\hline Kenari & $36,00 \mathrm{a}$ & $35,00 \mathrm{a}$ & $35,50 \mathrm{a}$ & $34,75 \mathrm{a}$ & 35,31 \\
\hline Kutilang & $34,00 \mathrm{~b}$ & $34,50 \mathrm{a}$ & $33,50 \mathrm{~b}$ & $33,00 \mathrm{~b}$ & 33,75 \\
\hline Murai & $32,75 \mathrm{c}$ & $32,75 \mathrm{~b}$ & $33,00 \mathrm{~b}$ & $34,25 \mathrm{a}$ & 33,19 \\
\hline Sriti & $33,00 \mathrm{c}$ & $33,50 \mathrm{~b}$ & $33,00 \mathrm{~b}$ & $35,00 \mathrm{a}$ & 33,63 \\
\hline Rerata & 33,94 & 33,94 & 33,75 & 34,25 & + \\
\hline CV & 2,65 & & & & \\
\hline
\end{tabular}

Keterangan :

(+) Terdapat interaksi antara kedua faktor.

Angka-angka pada kolom atau baris yang sama diikuti oleh huruf yang sama, tidak berbeda nyata pada uji Scott Knott dengan taraf kepercayaan 95\%. 
Tabel 14. Waktu Pembungaan (hari) Faktor Kultivar

\begin{tabular}{|c|c|c|c|c|c|}
\hline \multirow[b]{2}{*}{ Kultivar } & \multicolumn{4}{|c|}{ Enkapsulasi } & \multirow[b]{2}{*}{ Rerata } \\
\hline & Kontrol & $\begin{array}{c}\text { Tanpa } \\
\text { Enkapsulasi }\end{array}$ & $\begin{array}{c}\text { Enkapsulasi } \\
\text { Kaolinite }\end{array}$ & $\begin{array}{c}\text { Enkapsulasi } \\
\text { Montmorillonite }\end{array}$ & \\
\hline Kenari & $36,00 \mathrm{a}$ & $35,00 \mathrm{a}$ & $35,50 \mathrm{a}$ & $34,75 \mathrm{a}$ & 35,31 \\
\hline Kutilang & $34,00 \mathrm{a}$ & $34,50 \mathrm{a}$ & $33,50 \mathrm{a}$ & $33,00 \mathrm{a}$ & 33,75 \\
\hline Murai & $32,75 \mathrm{~b}$ & $32,75 \mathrm{~b}$ & $33,00 \mathrm{~b}$ & $34,25 \mathrm{a}$ & 33,19 \\
\hline Sriti & $33,00 \mathrm{~b}$ & $33,50 \mathrm{~b}$ & $33,00 \mathrm{~b}$ & $35,00 \mathrm{a}$ & 33,63 \\
\hline Rerata & 33,94 & 33,94 & 33,75 & 34,25 & + \\
\hline $\mathrm{CV}$ & 2,65 & & & & \\
\hline
\end{tabular}

Keterangan :

(+) Terdapat interaksi antara kedua faktor.

Angka-angka pada kolom atau baris yang sama diikuti oleh huruf yang sama, tidak berbeda nyata pada uji Scott Knott dengan taraf kepercayaan 95\%.

Waktu pembungaan setiap varietas berbeda-beda, umur berbunga Kenari 36 hari, Kutilang berkisar antara 35-38 hari, Murai 35 hari, dan Sriti 35 hari. Hal ini menandakan bahwa mikoriza mampu meningkatkan waktu pembungaan seluruh kultivar kacang hijau yang digunakan. Kombinasi antara pupuk kandang kambing dengan mikoriza mampu mempengaruhi generatif tanaman salah satunya yaitu mempercepat umur berbunga (Wicaksono, dkk., 2014).

Tabel 15. Umur Panen Polong Pertama (hari)

\begin{tabular}{lccccc}
\hline \multirow{2}{*}{ Kultivar } & \multicolumn{4}{c}{ Enkapsulasi } & Rerata \\
\cline { 2 - 5 } & Kontrol & $\begin{array}{c}\text { Tanpa } \\
\text { Enkapsulasi }\end{array}$ & $\begin{array}{c}\text { Enkapsulasi } \\
\text { Kaolinite }\end{array}$ & $\begin{array}{c}\text { Enkapsulasi } \\
\text { Montmorillonite }\end{array}$ & \\
\hline Kenari & 59,75 & 59,00 & 59,00 & 57,75 & $58,88 \mathrm{a}$ \\
Kutilang & 57,00 & 55,00 & 55,25 & 54,00 & $55,31 \mathrm{~b}$ \\
Murai & 52,75 & 53,25 & 52,00 & 55,00 & $53,25 \mathrm{c}$ \\
Sriti & 53,50 & 55,75 & 52,75 & 55,25 & $54,31 \mathrm{~b}$ \\
\hline \multicolumn{1}{c}{ Rerata } & $55,75 \mathrm{a}$ & $55,75 \mathrm{a}$ & $54,75 \mathrm{a}$ & $55,50 \mathrm{a}$ & - \\
\hline \multicolumn{1}{c}{ CV } & 3,54 & & & & \\
\hline
\end{tabular}

Keterangan :

(-) Tidak terdapat interaksi antara kedua faktor.

Angka-angka pada kolom atau baris yang sama diikuti oleh huruf yang sama, tidak berbeda nyata pada uji Scott Knott dengan taraf kepercayaan 95\%.

Hasil umur panen kacang hijau tidak menunjukkan adanya interaksi antara faktor enkapsulasi dengan faktor kultivar. Umur panen kacang hijau bervariasi tergantung pada jenis kultivar. Umur panen kultivar Kenari berkisar antara 60-65 hari, Kutilang berkisar antara 60-67 hari, Murai berkisar antara 62-65 hari, sedangkan Sriti berkisar antara 6065 hari. Hasil menunjukkan pemberian mikoriza mampu mempercepat umur panen 
Dinda Tria Handayani et al., / Vegetalika. 2018. 7(4): 39-58

polong masak pada kacang hijau. Umur panen kultivar Kenari 58,88 hari, Kutilang 55,31 hari, Murai 53,25 hari, dan Sriti 54,31 hari.

Tabel 16. Bobot Segar Saat panen (gram)

\begin{tabular}{lccccc}
\hline \multirow{2}{*}{ Kultivar } & \multicolumn{5}{c}{ Enkapsulasi } \\
\cline { 2 - 5 } & Kontrol & $\begin{array}{c}\text { Tanpa } \\
\text { Enkapsulasi }\end{array}$ & $\begin{array}{c}\text { Enkapsulasi } \\
\text { Kaolinite }\end{array}$ & $\begin{array}{c}\text { Enkapsulasi } \\
\text { Montmorillonite }\end{array}$ & Rerata \\
\hline Kenari & 19,57 & 20,10 & 23,54 & 21,93 & $21,28 \mathrm{~b}$ \\
Kutilang & 21,89 & 22,89 & 23,48 & 23,36 & $22,90 \mathrm{~b}$ \\
Murai & 29,82 & 29,39 & 40,10 & 33,39 & $33,17 \mathrm{a}$ \\
Sriti & 31,49 & 28,29 & 35,38 & 34,01 & $32,29 \mathrm{a}$ \\
\hline Rerata & $25,69 \mathrm{a}$ & $25,17 \mathrm{a}$ & $30,63 \mathrm{a}$ & $28,17 \mathrm{a}$ & - \\
\hline CV & 24,74 & & &
\end{tabular}

Keterangan :

(-) Tidak terdapat interaksi antara kedua faktor.

Angka-angka pada kolom atau baris yang sama diikuti oleh huruf yang sama, tidak berbeda nyata pada uji Scott Knott dengan taraf kepercayaan 95\%.

Interaksi antara akar dengan mikoriza mampu meningkatkan serapan hara dalam media tanam, terutama unsur P. Hifa eksternal mampu menyediakan permukaan yang lebih efektif dalam menyerap unsur hara dari media kemudian dipindahkan ke akar inang sehingga mampu menghasilkan tajuk yang lebih optimal (Muis, dkk., 2016).

Tabel 17. Bobot Kering Saat panen (gram)

\begin{tabular}{cccccc}
\hline \multirow{2}{*}{ Kultivar } & \multicolumn{4}{c}{ Enkapsulasi } & Rerata \\
\cline { 2 - 5 } & Kontrol & $\begin{array}{c}\text { Tanpa } \\
\text { Enkapsulasi }\end{array}$ & $\begin{array}{c}\text { Enkapsulasi } \\
\text { Kaolinite }\end{array}$ & $\begin{array}{c}\text { Enkapsulasi } \\
\text { Montmorillonite }\end{array}$ \\
\hline Kenari & 12,75 & 12,87 & 17,04 & 13,05 & $13,93 \mathrm{~b}$ \\
Kutilang & 10,94 & 10,92 & 19,21 & 15,80 & $14,22 \mathrm{~b}$ \\
Murai & 18,84 & 18,56 & 24,06 & 23,86 & $21,33 \mathrm{a}$ \\
Sriti & 21,75 & 21,90 & 24,95 & 23,16 & $22,94 \mathrm{a}$ \\
\hline Rerata & $16,07 \mathrm{~b}$ & $16,06 \mathrm{~b}$ & $21,31 \mathrm{a}$ & $18,97 \mathrm{a}$ & - \\
\hline CV & 25,96 & & & & \\
\hline
\end{tabular}

Keterangan :

(-) Tidak terdapat interaksi antara kedua faktor.

Angka-angka pada kolom atau baris yang sama diikuti oleh huruf yang sama, tidak berbeda nyata pada uji Scott Knott dengan taraf kepercayaan 95\%.

Interaksi antara mikoriza dengan tanaman mampu meningkatkan bobot kering tajuk, akar, dan total, karena mikoriza mampu meningkatkan kemampuan penyerapan unsur hara dan air oleh akar sehingga terjadi peningkatan pertumbuhan tajuk tanaman (Prasasti, dkk., 2013). Semakin tinggi bobot kering saat panen menunjukkan semakin tingginya kandungan air dalam tumbuh tanaman. 
Tabel 18. Jumlah Polong per Tanaman

\begin{tabular}{lccccc}
\hline \multirow{2}{*}{ Kultivar } & \multicolumn{4}{c}{ Enkapsulasi } & Rerata \\
\cline { 2 - 5 } & Kontrol & $\begin{array}{c}\text { Tanpa } \\
\text { Enkapsulasi }\end{array}$ & $\begin{array}{c}\text { Enkapsulasi } \\
\text { Kaolinite }\end{array}$ & $\begin{array}{c}\text { Enkapsulasi } \\
\text { Montmorillonite }\end{array}$ \\
\hline Kenari & 23,50 & 23,25 & 31,25 & 32,25 & $27,56 \mathrm{~b}$ \\
Kutilang & 27,50 & 27,75 & 32,75 & 33,75 & $30,44 \mathrm{~b}$ \\
Murai & 37,75 & 25,75 & 35,50 & 46,00 & $36,25 \mathrm{a}$ \\
Sriti & 32,50 & 26,50 & 36,00 & 43,25 & $34,56 \mathrm{a}$ \\
\hline \multicolumn{1}{c}{ Rerata } & $30,31 \mathrm{c}$ & $25,81 \mathrm{c}$ & $33,88 \mathrm{~b}$ & $38,81 \mathrm{a}$ & - \\
\hline \multicolumn{1}{c}{ CV } & 15,83 & & & & \\
\hline
\end{tabular}

Keterangan :

(-) Tidak terdapat interaksi antara kedua faktor.

Angka-angka pada kolom atau baris yang sama diikuti oleh huruf yang sama, tidak berbeda nyata pada uji Scott Knott dengan taraf kepercayaan 95\%.

Mikoriza mampu meningkatkan jumlah bunga viabel sehingga terjadi peningkatan jumlah pembentukan polong bernas. Jumlah polong yang banyak menandakan metabolisme dalam tubuh tanaman yang baik.

Tabel 19. Jumlah Biji per Polong

\begin{tabular}{lccccc}
\hline \multirow{2}{*}{ Kultivar } & \multicolumn{4}{c}{ Enkapsulasi } & Rerata \\
\cline { 2 - 5 } & Kontrol & $\begin{array}{c}\text { Tanpa } \\
\text { Enkapsulasi }\end{array}$ & $\begin{array}{c}\text { Enkapsulasi } \\
\text { Kaolinite }\end{array}$ & $\begin{array}{c}\text { Enkapsulasi } \\
\text { Montmorillonite }\end{array}$ & \\
\hline Kenari & 9,60 & 9,74 & 10,01 & 10,36 & $9,93 \mathrm{~b}$ \\
Kutilang & 8,96 & 8,94 & 9,56 & 9,62 & $9,27 \mathrm{c}$ \\
Murai & 10,29 & 10,18 & 11,04 & 11,07 & $10,65 \mathrm{a}$ \\
Sriti & 10,85 & 10,55 & 10,69 & 10,96 & $10,76 \mathrm{a}$ \\
\hline \multicolumn{1}{c}{ Rerata } & $9,93 \mathrm{~b}$ & $9,85 \mathrm{~b}$ & $10,33 \mathrm{a}$ & $10,50 \mathrm{a}$ & - \\
\hline \multicolumn{1}{c}{ CV } & 5,20 & & & & \\
\hline
\end{tabular}

Keterangan :

(-) Tidak terdapat interaksi antara kedua faktor.

Angka-angka pada kolom atau baris yang sama diikuti oleh huruf yang sama, tidak berbeda nyata pada uji Scott Knott dengan taraf kepercayaan 95\%.

Tersedianya air dalam jumlah yang cukup mampu mempertahankan kehijauan daun lebih lama dan aktivitas fotosintesis meningkat sehingga fotosintat cukup memenuhi kebutuhan tanaman baik pada fase vegetatif maupun fase generatif saat pengisian polong dan hasil biji kering. Tersedianya air juga mampu meningkatkan jumlah polong isi (Muis, dkk., 2016). 
Dinda Tria Handayani et al., / Vegetalika. 2018. 7(4): 39-58

Tabel 20. Bobot Biji per Tanaman (gram)

\begin{tabular}{lccccc}
\hline \multirow{2}{*}{ Kultivar } & \multicolumn{5}{c}{ Enkapsulasi } \\
\cline { 2 - 5 } & Kontrol & $\begin{array}{c}\text { Tanpa } \\
\text { Enkapsulasi }\end{array}$ & $\begin{array}{c}\text { Enkapsulasi } \\
\text { Kaolinite }\end{array}$ & $\begin{array}{c}\text { Enkapsulasi } \\
\text { Montmorillonite }\end{array}$ & Rerata \\
\hline Kenari & 6,88 & 7,77 & 11,18 & 9,50 & $8,83 \mathrm{~b}$ \\
Kutilang & 7,44 & 9,09 & 11,04 & 9,14 & $9,18 \mathrm{~b}$ \\
Murai & 15,83 & 10,65 & 15,50 & 15,88 & $14,46 \mathrm{a}$ \\
Sriti & 14,70 & 11,95 & 13,19 & 9,81 & $12,41 \mathrm{a}$ \\
\hline \multicolumn{1}{c}{ Rerata } & $11,21 \mathrm{a}$ & $9,86 \mathrm{a}$ & $12,72 \mathrm{a}$ & $11,08 \mathrm{a}$ & - \\
\hline \multicolumn{1}{c}{ CV } & 33,2 & & & & \\
\hline
\end{tabular}

(-) Tidak terdapat interaksi antara kedua faktor.

Angka-angka pada kolom atau baris yang sama diikuti oleh huruf yang sama, tidak berbeda nyata pada uji Scott Knott dengan taraf kepercayaan 95\%.

Pemberian mikoriza justru menurunkan bobot biji kering pada tanaman kacang hijau. Penurunan hasil ini menunjukkan bahwa sebagian besar hasil fotosintesis didistribusikan pada fase vegetatif untuk pertumbuhan sehingga pada fase pembentukan polong, pengisian biji berkurang dan mengakibatkan penurunan pada variabel hasil tanaman.

Tabel 21. Bobot Seratus Biji (gram)

\begin{tabular}{lccccc}
\hline \multirow{2}{*}{ Kultivar } & \multicolumn{4}{c}{ Enkapsulasi } & Rerata \\
\cline { 2 - 5 } & Kontrol & $\begin{array}{c}\text { Tanpa } \\
\text { Enkapsulasi }\end{array}$ & $\begin{array}{c}\text { Enkapsulasi } \\
\text { Kaolinite }\end{array}$ & $\begin{array}{c}\text { Enkapsulasi } \\
\text { Montmorillonite }\end{array}$ & \\
\hline Kenari & 2,88 & 3,03 & 6,76 & 5,05 & $4,43 \mathrm{a}$ \\
Kutilang & 2,39 & 3,39 & 6,47 & 6,26 & $4,63 \mathrm{a}$ \\
Murai & 7,19 & 3,96 & 7,29 & 5,09 & $5,88 \mathrm{a}$ \\
Sriti & 4,60 & 2,95 & 5,06 & 3,35 & $3,99 \mathrm{a}$ \\
\hline \multicolumn{1}{c}{ Rerata } & $4,26 \mathrm{~b}$ & $3,33 \mathrm{~b}$ & $6,40 \mathrm{a}$ & $4,94 \mathrm{~b}$ & - \\
\hline \multicolumn{7}{c}{ CV } & 5,2 & & & & \\
\hline
\end{tabular}

(-) Tidak terdapat interaksi antara kedua faktor.

Angka-angka pada kolom atau baris yang sama diikuti oleh huruf yang sama, tidak berbeda nyata pada uji Scott Knott dengan taraf kepercayaan 95\%.

Mikoriza mampu memperbaiki mutu biji saat panen kacang hijau. Peningkatan jumlah dan ukuran biji berbanding lurus dengan bobot seratus biji. Pemberian mikoriza mampu mempengaruhi bobot 100 butir jagung (Sasli dan Ruliansyah, 2012). Biji mengalami tahap histo differentiation yang terdiri dari pembelahan dan pembesaram sel kemudian diikuti dengan pengisian material biji dalam bentuk cadangan makanan (endosperma). Pola ini ditunjukkan dalam bentuk terjadinya peningkatan bobot kering biji yang diikuti dengan adanya penurunan kadar air secara bertahap. Pemberian 
Dinda Tria Handayani et al., / Vegetalika. 2018. 7(4): 39-58

mikoriza mampu menghasilkan bobot seratus biji yang lebih baik pada berbagai varietas kedelai.

\section{KESIMPULAN}

1. Mikoriza berperan untuk memperbaiki mutu benih kacang hijau pada lahan pasir sehingga mampu menghasilkan tanaman yang lebih baik.

2. Mikoriza mempengaruhi pertumbuhan dan perkembangan tanaman baik pada masa vegetatif maupun generatif.

3. Enkapsulasi dengan mineral lempung montmorillonite mampu memberikan hasil yang baik pada hasil gaya berkecambah, jumlah kolonisasi akar, indeks vigor hipotetik, komponen bibit, pertumbuhan jumlah daun 60 hst, panjang akar, volume akar, jumlah polong, dan jumlah biji per polong.

4. Kultivar Murai mampu meningkatkan hasil imdeks vigor, indeks vigor hipotetik, bobot segar bibit, pertumbuhan tinggi tanaman $60 \mathrm{hst}$, tinggi tanaman panen, jumlah daun panen, volume akar panen, jumlah polong, bobot biji per tanaman, dan bobot seratus biji serta mampu mempercepat waktu berbunga dan umur panen polong pertama.

\section{DAFTAR PUSTAKA}

Ai, N. S. dan P. Torey. 2013. Karakter morfologi akar sebagai indikator kekurangan air pada tanaman. Jurnal Bioslogos 3 (1) : 31-39.

Coppeland. 1980. Princiles of Seed Science and Technology. Burges Publ. Co. Minneapolis, Minnesota.

Havugimana, E., B. S. Bhople, E. Byiringiro, dan J. P. Mugabo. 2016. Role of dual inoculation of Rhizobium and Arbuscular Mycorrhizal (AM) Fungi on pulse crops production. Walailak J. Sci and Tech 13 (1):1- 7.

Muis, R., M. Ghulamahdi, M. Melati, Purwono, dan I. Mansur. 2016. Kompatibilitas fungi mikoriza arbuskular dengan tanaman kedelai pada budi daya jenuh air. Penelitian Pertanian Tanaman Pangan 35 (3) : 229-237.

Novita dan F. C. Suwarno. 2014. Viabilitas benih melon (Cucumis melo L.) pada kondisi optimum dan sub-optimum setelah diberi perlakuan invigorasi. Bul. Agrohorti 2 (1) : $59-65$.

Nurhayati, Razali, dan Zuraida. 2014. Peranan berbagai jenis bahan pembenah tanah terhadap status hara $p$ dan perkembangan akar kedelai pada tanah gambut asal ajamu sumatera utara. Floratek $9: 29-38$. 
Dinda Tria Handayani et al., / Vegetalika. 2018. 7(4): 39-58

Permanasari, I., K. Dewi, M. Irfan, dan A. T. Arminudin. 2016. Peningkatan efisiensi pupuk fosfat melalui aplikasi mikoriza pada kedelai. Agroteknologi 6(2) : 23-30.

Prasasti, O. H., K. I. Purwanti, dan S. Nurhatika. 2013. Pengaruh mikoriza Glomus fasciculatum terhadap pertumbuhan vegetatif kacang tanah yang terinfeksi patogen Sclerotium rolfsii. Jurnal Sains dan Seni POMITS 2 (2) : 74-78.

Rahayu, A. Y. 2010. Pengaruh perlakuan benih dengan cendawan mikoriza arbuskula dan dosis pupuk fosfat terhadap pertumbuhan tanaman dan hasil kedelai. Departemen Agronomi dan Hortikultura. Fakultas Pertanian. Institut Pertanian Bogor, Bogor.

Sampurno, Elsie, dan O. Riana. 2010. Pemanfaatan cendawan mikoriza arbuskular (cma) pada berbagai jenis tanah terhadap pertumbuhan kacang tanah (Arachis hipogaea L.). SAGU 9 (1) : 28-37.

Sasli, I. dan A. Ruliansyah. 2012. Pemanfaatan mikoriza arbuskula spesifik lokasi untuk efisiensi pemupukan pada tanaman jagung di lahan gambut tropis. Agrovigor 5 (2) : $65-76$.

Wahyono, N. D. dan S. Rahayu. 2014. Aplikasi pupuk biourine pada beberapa varitas kacang hijau (Vigna radiata L.) terhadap produksi kacang hijau. INOVASI 14(1) : 110-116.

Wicaksono, M. I., M. Rahayu, dan Samanhudi. 2014. Pengaruh pemberian mikoriza dan pupuk organik terhadap pertumbuhan bawang putih. Jurnal IImu IImu Pertanian $29(1): 35-44$.

Widiastuti, H., E. Guhardia, N. Sukarno, I. K. Darusman, D. H. Goenadi, dan S. Smith. 2003. Arsitektur akar bibit kelapa sawit yang diinokulasi beberapa cendawan mikoriza arbuskula. Menara Perkebunan 71 (1) : 28-43. 